\title{
DEPARTMENT OF PUBLICATIONS
}

\section{BOOK REVIEWS}

Municipal Life and Government in Germany. By William Harbutt Dawson. London: Iongmans, Green and Company. $\$ 3.75$.

The methods and results of German city administration have long since commanded admiration in America. Yet the problem of getting a fair and accurate account of these things has been one of considerable difficulty. Very little of any value has been written in English on the administrative side of German local government; and the average American student of municipal affairs has neither the time nor the patience to work his way through the various German year books of statistics and manuals of administrative law. Mr. Dawson has therefore undertaken a useful task in his attempt to give English readers a clear statement of what the German cities set out to do and how far they succeed in doing it.

The volume deals both with the organization of German city government and with its day-to-day functions. The larger portion of the book, however,' is devoted to the latter subject. Every important branch of civic activity gets its share of attention: city planning and land policy, housing, public health, poor relief, finance and municipal operation of public utilities, each has one or more chapters. The treatment is both descriptive and critical, but on the whole the author's attitude towards German methods is distinctly sympathetic. He sees much to admire in all branches of German administration and much that might profitably find imitation in England. Too often, however, this admiration carries him beyond the bounds of accuracy and in some cases to general statements which are absurd. Here is a good example:

"Let the town clerk of an English municipal borough," Mr. Dawson tells us, "be asked what powers his council can exercise, and he will point to volumes of laws and heaps of text books.. for nothing can be done for which there is not express legal sanction. . . On the other hand, let the mayor of a German town be similarly questioned, and he will at once answer that there is practically no limit to the administrative powers which he and his colleagues may exercise; they can do everything, in fact, that the good government of the town may seem. to require." (p.33.)

The German mayor who would make any such answer would be talking nonsense, as the author himself unwittingly proves in the latter part of the same chapter (pp. 43-57). If $\mathrm{Mr}$. Dawson had placed more dependence upon the published laws of the land and less upon conversations with members of the municipal bureaucracy, he would have kept many such sweeping statements from marring the pages of his book. There is no more certain way of getting an exaggerated statement of a German official's powers and influence than by taking the ipse dixit of the official himself.

On the other hand, the author has shown. great diligence in hunting up figures and considerable skill in putting them together. The four chapters on municipal taxation, for example, give an excellent survey of this complicated subject. The discussions of housing policy, poor relief and local school administration, while somewhat sketchy, are also worth the attention of the American reader who is interested in these things. Other chapters, such as 
those relating to trading enterprises and social welfare work, contain little more than an array of statistical details. Unfortunately, moreover, the author gives us, in most cases, no indication as to the source of his financial data. Anyone who has had much occasion to use the financial reports of German cities and has learned how easily they can be misinterpreted, will regard this avoidance of references as a very grave defect. Nevertheless, a volume which is so encyclopedic in its details is sure to prove of service as a work of reference.

William Bennett Munro.

Harvard University.

Applied City Government. By Herman G. James. New York: Harper and Brothers. 75 cents.

The disagreeable side of the critic's duty may be quickly completed in connection with this book by noting the inadequacy of the title to convey an idea of the nature of the contents. The work is, it is true, a constructive application of scientific knowledge about city government; but it is an application of a limited part of that knowledge only. It is concerned with but a single problem of city government, that of organization, that of the constitution of the city. It deals only with the city charter.

The sub-title reads "the principles and practice of city charter making." Here, again, a formal criticism may be made. By "principles," the author indicates his discussion of the various matters with which a charter must deal; and as "practice," he offers concrete provisions which together form a model charter conforming to the conclusions reached in the critical discussion. The discussion of principles, however, leads the author to the acceptance of certain features of organization and to the positive rejection of others. The result is that the constructive treatment is confined to a single type of city government-the commission-manager form. The principles of the recall, general referendum and initiative are approved, and incorporated as essentials. In short, the book presents, and presents only, the most advanced ideas on city organization.

Only incidental aid is offered to those cities which prefer to remain under one of the older forms of organization. Taken, however, in conjunction with Nathan Matthews "Municipal Charters," constructive material is now available for the three important forms of American city government to-day: the responsible-executive type, the commission type, and the commission-manager type.

The work under review is probably the most important acquisition that can be made by the library of a city that is contemplating a manager form of government. The advantages of this type and the principles to be applied in its organization are stated with the utmost succinctness. The various matters proper to a city charter are discussed in logical sequence, the discussion being immediately followed in each case by a model provision. The discussion and provisions are not exhaustive. Only the most strictly essential points are covered. The model is a skeleton only, but an extremely useful one. As director of the bureau of municipal research and reference at the University of Texas, Dr. James has had experience that enables him to anticipate the chief questions confronting charter commissions. A well-selected bibliography of the commission and manager plans is appended.

University of Michigan.

Robert T. Crane.

A Treatige on the Law of Public Utilitues Operating in Cities and Towns. By Oscar L. Pond, Indianapolis: The Bobbs-Merrill Company. \$6.

This treatise on the law of municipal utilities purports (1) "to ascertain both the nature of the municipal corporation as expressed in the law and in the construction which the courts have given to the powers conferred upon the municipality by the state, to discover what limitations are placed on municipal activity by our constitutions, as construed by the courts; and (2) how far the judicial construction 